\title{
Ewa Ronowska
}

naukowiec niezależny

ORCID: 0000-0001-9740-3153

\section{Problem działalności budowlanej Salomona w świetle najnowszych odkryć archeologicznych w Megiddo}

\begin{abstract}
Abstrakt: Artykuł przedstawia najnowsze ustalenia w kwestii identyfikacji monumentalnych struktur filarowych i bramy 2156 w Megiddo, które zostały oparte przede wszystkim na analizie danych archeologicznych zebranych w trakcie prac wykopaliskowych w sezonie 2018 (brama 2156) oraz podczas badań wznowionych w roku 1998 i kontynuowanych w kolejnych sezonach (miasto warstwy IV). Wyniki badań wskazują, że monumentalne budowle - stajnie i sześciokomorowa brama - odkryte w Megiddo jeszcze w latach dwudziestych XX wieku, początkowo łączone z panowaniem Salomona, w rzeczywistości najprawdopodobniej powstały w czasach rozkwitu Północnego Królestwa i związane są z działalnością budowlaną jego władców (królów z dynastii Omrydów i Jeroboama II).
\end{abstract}

Słowa kluczowe: Megiddo, Biblia, archeologia, Królestwo Północne, dynastia Omrydów, Jeroboam II, Salomon

\section{Wprowadzenie}

Starożytne Megiddo zostało zidentyfikowane w początkach XX wieku. Po długich sporach rozpoznano je ostatecznie we wznoszącym się na wysokość około $70 \mathrm{~m}$ ponad Doliną Jezreel wzgórzu noszącym arabską nazwę Tell El-Mutesellim. Stanowisko położone jest w północnym Izraelu w pobliżu kibucu Megiddo, około $30 \mathrm{~km}$ na południowy wschód od Hajfy $\left(32^{\circ} 35^{\prime} 06^{\prime \prime} \mathrm{N}, 35^{\circ} 11^{\prime} 03^{\prime \prime} \mathrm{E}\right)$. Dziś Megiddo jest ważnym węzłem komunikacyjnym na głównej drodze łączącej środkowy Izrael z Dolną Galileą i regionami północnymi. Funkcję tę pełni niemal bez zmian od tysiącleci. Obecny tell kryje dwadzieścia warstw obejmujących pozostałości osadnictwa 
istniejącego tu na przestrzeni ponad sześciu tysiącleci - od przedceramicznego neolitu po okres perski ${ }^{1}$. Ze względu na strategiczne położenie przy jednym z głównych szlaków starożytnego Bliskiego Wschodu, który łączył Egipt z Syrią, Anatolią i Mezopotamią, Megiddo było przez stulecia jednym z kluczowych miast w regionie. Okolice Megiddo wielokrotnie w swej historii stawały się polem bitewnym - walczyli tutaj egipscy faraonowie, Kananejczycy, Filistyni, Midianici, Amalekici, Izraelici i Judejczycy, Hasmoneusze, władcy hellenistyczni, Rzymianie, Bizantyjczycy, Arabowie, krzyżowcy, Mongołowie, mamelucy, Napoleon, Turcy Osmańscy, Niemcy, wojska brytyjskie i wreszcie współczesne izraelskie i arabskie siły zbrojne ${ }^{2}$. Nie jest zatem zaskakujące, że w tradycji chrześcijańskiej, opartej na Apokalipsie św. Jana, „góra Megiddo” jest miejscem rozstrzygającego starcia między siłami dobra i zła i ostatecznego triumfu Chrystusa nad Antychrystem: „I zgromadził ich na miejscu, które po hebrajsku nazywa się Armagedon (Ap $\mu \alpha \gamma \varepsilon \delta \delta \omega ́ v) "(A p ~ 16,16)^{3}$.

Od lat Tel Megiddo jest miejscem badanym przez kolejne ekspedy$\mathrm{cje}^{4}$. Pierwsze wykopaliska w tym miejscu zostały przeprowadzone

1 O znaczeniu Megiddo, jego nazwie, miejscu w Biblii i w źródłach pozabiblijnych oraz dziejach pisałam w artykule E. Ronowska, „Biblijne Megiddo”, 5-41.

2 E.H. Cline, The Battles of Armageddon, 1-3.

3 Wszystkie cytaty biblijne podaję za Biblią Warszawską.

4 Wyniki tych prac zostały przedstawione w następujących publikacjach: G. Schumacher, Tell el-Mutesellim 1, Leipzig 1908; C. Watzinger, Tell el-Mutesellim 2, Leipzig 1929; C.S. Fisher, The Excavation of Armageddon, Chicago (IL) 1929; P.L.O. Guy, New Light from Armageddon: Second Provisional Report (1927-29) on the Excavations at Megiddo in Palestine, Chicago (IL) 1931; H.G. May, Material Remains of the Megiddo Cult, Chicago (IL) 1935; R.S. Lamon, The Megiddo Water System, Chicago (IL) 1935; P.L.O. Guy, Megiddo Tombs, Chicago (IL) 1938; R.S. Lamon, G.M. Shipton, Megiddo I. Seasons of 1925-34: Strata I-V, Chicago (IL) 1939; G.M. Shipton, Notes on the Megiddo Pottery of Strata VI-XX, Chicago (IL) 1939; G. Loud, The Megiddo Ivories, Chicago (IL) 1939; tenże, Megiddo II. Seasons of 1935-39: Text and Plates, Chicago (IL) 1948; A. Zarzecki-Peleg, Yadin's Expedition to Megiddo. Final Report of the Archaeological Excavations (1960, 1966, 1967 and 1971/72 Seasons) (QEDEM 56), Jerusalem 2016. Wyniki badań wszystkich ekspedycji przed rokiem 1992 przedstawiają publikacje: G.I. Davies, Megiddo, Cambridge 1986; A. Kempinsky, Megiddo: A City State and Royal Centre in North Israel, Münich 1989. Rezultaty badań prowadzonych przez Uniwersytet w Tel Awiwie publikowane są w tomach będących kontynuacją publikacji podsumowujących 
w latach 1903-1905 przez inżyniera Gottlieba Schumachera, reprezentującego Niemieckie Towarzystwo Studiów nad Palestyną. Wykonano wówczas w poprzek wzgórza wykop o wymiarach 18 na 23 metry - przebiegający z północy na południe - oraz kilka mniejszych prób sondażowych w innych częściach terenu, rozpoznając siedem poziomów osadnictwa. Wśród odkrytych budowli Schumacher zidentyfikował m.in. dwa ,pałace” i znajdujące się pod nimi grobowce „królewskie” z okresu środkowego i późnego brązu (warstwa II i III). Z epoki żelaza, gdy Megiddo było izraelskim miastem, pochodzą odsłonięte przez tę ekspedycję monumentalne budowle opisywane jako świątynia (z macewami) i pałac (warstwa V). Jeszcze pod koniec lat dwudziestych XX wieku Carl Watzinger określił czas ich powstania na IX wiek przed Chr., a zatem na okres panowania władców północnego królestwa (Izraela) Omriego i Achaba.

Prace wykopaliskowe w Megiddo kontynuował od 1925 r. Instytut Orientalny Uniwersytetu w Chicago i prowadził je niemal do wybuchu II wojny światowej. Kierowali nimi kolejno Clarence Fisher, Philip Guy i Gordon Loud. Ekspedycja ta zidentyfikowała w Megiddo dwadzieścia głównych poziomów osadnictwa, datowanych od VI tysiąclecia (neolit, chalkolit) do V wieku przed Chr. Najważniejsze odkrycia ekspedycji chicagowskiej to m.in.: pozostałości konstrukcji, w której rozpoznano sanktuarium z wczesnego brązu (lata ok. 34003000 przed Chr.); Okrągły Ołtarz, ,wyżyna” służąca składaniu ofiar,

wyniki prac prowadzonych przez Uniwersytet w Chicago. Dotychczas ukazały się następujące wydania: I. Finkelstein, D. Ussishkin, B. Halpern (red.), Megiddo III. The 1992-1996 Seasons (Monographs of the Institute of Archaeology of Tel Aviv University 18), t. 1-2, Tel Aviv 2000; I. Finkelstein, D. Ussishkin, B. Halpern (red.), Megiddo IV. The 1998-2000 Seasons (Monographs of the Institute of Archaeology of Tel Aviv University 24), t. 1-2, Tel Aviv 2006; I. Finkelstein, D. Ussishkin, E.H. Cline (red.), Megiddo V. The 2004-2008 Seasons (Monographs of the Institute of Archaeology of Tel Aviv University 31), t. 1-3, Winona Lake (IN) 2013; w przygotowaniu: I. Finkelstein, E.H. Cline, M.A.S. Martin (red.), Megiddo VI: The 2010-2014 Seasons (Monographs of the Institute of Archaeology of Tel Aviv University).

Zwięzłe informacje na temat najważniejszych odkryć dostępne są także na stronie internetowej ekspedycji: https://megiddoexpedition.wordpress.com/tel-aviv-university-excavations/; https://megiddoexpedition.wordpress.com/revelations-from-megiddo/ (dostęp 3.05.2020). 
wzniesiona w okresie wczesnego brązu III; masywne kamienne mury (Walls 4045 i 4045A, warstwa XVIII), które interpretuje się jako część wielkich fortyfikacji lub mury oporowe mające związek z tzw. Wielką Świątynią; pałac datowany na epokę wczesnego brązu; trzy świątynie w kształcie wieży (Tower Temples I-III); pałac z okresu późnego brązu; Pałac Południowy z epoki żelaza (z czasów królów Izraela); jedno ze skrzydeł tzw. bramy Salomona; kilka segmentów murów miejskich (City Wall 325) z przylegającymi do nich po obu stronach budynkami bramnymi.

Kolejne badania archeologiczne prowadził w Megiddo Yigael Yadin z Uniwersytetu Hebrajskiego w Jerozolimie (w latach 1960, 1966, 1967 oraz w sezonie 1971/72). Jego celem było wyjaśnienie skomplikowanych problemów stratygraficznych związanych z pozostałościami obiektów, szczególnie fortyfikacji, z okresu panowania króla Salomona. O kontrowersjach związanych z rezultatami badań tego uczonego będzie mowa w szerszym zakresie niżej.

Prace wykopaliskowe w Megiddo zostały podjęte przez Uniwersytet w Tel Awiwie we współpracy z Uniwersytetem Stanowym w Pensylwanii pod kierownictwem Israela Finkelsteina, Davida Ussishkina oraz Barucha Halperna. Prace te, mające na celu długoterminowe i systematyczne badania Tel Megiddo, rozpoczęły się od dwóch krótkich ekspedycji w 1992 i 1993 roku. Począwszy od pierwszego pełnego sezonu wykopaliskowego, który miał miejsce w 1994 r., badania prowadzone są co dwa lata, obejmując stopniowo następujące obszary:

- Obszar F - znajduje się na dolnym tarasie, zawiera pozostałości ziemnego wału z okresu środkowego brązu, domów mieszkalnych z epoki późnego brązu I oraz z epoki żelaza I, a także monumentalnego budynku z okresu późnego brązu II;

- Obszar $\mathrm{G}$ - z bramą miejską z epoki późnego brązu, odkrytą przez zespół Uniwersytetu w Chicago (obszar AA);

- Obszar H - w północno-zachodniej krawędzi wzgórza; badanie koncentrowało się tu na określeniu związku między pałacami asyryjskimi, warstwą IVA zawierającą ślady zniszczeń oraz stratygrafią epoki żelaza; 
- Obszar J - tutaj celem było ponowne przebadanie świątyń z wczesnej epoki brązu, odkrytych przez ekspedycję Uniwersytetu w Chicago w obszarze BB;

- Obszar K - znajduje się w południowo-wschodnim skraju tellu, zawiera pozostałości budynków mieszkalnych epoki żelaza I-II;

- Obszar L - tutaj ponownie przebadano pałac 6000 odsłonięty przez Y. Yadina i ,północne stajnie” częściowo odkryte przez zespół Uniwersytetu w Chicago;

- $\quad$ Obszar M - mieści się w centrum tellu, w okolicach wielkiego rowu biegnącego wzdłuż osi północ-południe, który wykopał przed laty G. Schumacher; prace na tym obszarze podjęto w celu ponownego zbadania monumentalnego grobowca komnatowego oraz budowli nazwanej przez jej odkrywcę Nordburgiem;

- $\quad$ Obszar N - znajduje się w północno-zachodniej części wzgórza i zawiera pozostałości budowli począwszy od epoki środkowego brązu III po późną epokę brązu I;

- Obszar P - w północnej części wzgórza, gdzie prace zostały podjęte z inicjatywy izraelskiego Zarządu Ochrony Przyrody i Parków Narodowych;

- $\quad$ Obszar Q - położony w południowej części tellu, gdzie odkryto pozostałości pochodzące z okresu późnego brązu III, duży budynek z epoki żelaza IIA oraz warstwę zawierającą ślady zniszczeń z okresu późnego żelaza I;

- Obszar S - znajduje się w północnej części tellu, zawiera pozostałości monumentalnej struktury z epoki środkowego brązu;

- Obszar X - położony po zachodniej stronie wzgórza, otwarty w sezonie 2016, zawiera pozostałości konstrukcji pochodzących z VIII i VII wieku przed Chr. (późne żelazo II; warstwy III-II);

- $\quad$ Obszar Z - otwarty w sezonie 2018, obejmujący tzw. ,bramę Salomona" wraz z przyległościami.

Obecnie zespół Uniwersytetu w Tel Awiwie pracuje pod kierownictwem Israela Finkelsteina, Maria A.S. Martina oraz Matthew 
J. Adamsa5 . W ostatnim czasie rozpoczęta została również współpraca z Collège de France.

Należy podkreślić, że problematyka związana ze stratygrafią i chronologią oraz interpretacja wyników badań Tel Megiddo od lat budzą kontrowersje, co wynika z wielu przyczyn, wśród których za najważniejsze trzeba uznać różne metodologie badań stosowane przez poszczególne ekspedycje ${ }^{6}$ oraz różne założenia badawcze, czasem zdominowane przez kwestie ideologiczne. Sytuacja ta prowadzi często do konieczności reinterpretacji czy ponownych ocen materiału już opublikowanego i skomentowanego. Do najbardziej kontrowersyjnych zagadnień należy określenie chronologii poszczególnych warstw stanowiska, a co za tym idzie - datowanie znalezisk w nich występujących.

\section{Datowanie epoki żelaza}

W archeologii biblijnej szczególnie dyskusyjne jest ustalenie bezwzględnych dat odnoszących się do epoki żelaza na obszarze Palestyny. Dzieje się tak ze względu na kontrowersje związane z najstarszym okresem historii starożytnego Izraela oraz dyskurs dotyczący procesu formowania się Biblii. Względna chronologia Lewantu w epoce żelaza, obejmująca sekwencję faz typologii ceramiki opartą na stratygrafii, jest obecnie dobrze ugruntowana i w miarę uzgodniona, co oczywiście nie oznacza pełnej jednomyślności w tej kwestii wśród badaczy ${ }^{7}$. W odniesieniu do chronologii bezwzględnej zgody nie ma, a dyskusja doprowadziła do wyodrębnienia się dwóch

5 Matthew J. Adams jest dyrektorem Albright Institute of Archaeological Research w Jerozolimie i prezesem American Archaeology Abroad.

6 Przykładowo: metoda wdrożona przez Uniwersytet Chicago polegała na zdejmowaniu, jedna po drugiej, każdej warstwy stanowiska aż do skalnego podłoża. Była to metoda niewykonalna ze względu na olbrzymi rozmiar obszaru badań, ponadto badanie jednorazowo pojedynczej warstwy uniemożliwiało dokonanie właściwej oceny stratygrafii terenu. Ten poważny błąd metodologiczny stanowił przyczynę ogromnego zamieszania, które utrudniało prawidłową interpretację znalezisk. Kiedy stało się to oczywiste, badacze skoncentrowali swoje wysiłki na wybranych obszarach tellu. Zob. I. Finkelstein, D. Ussishkin, „Back to Megiddo”, 30.

7 I. Finkelstein, E. Piasetzky, ,The Iron Age Chronology Debate”, 50; A. Mazar, „The Debate over the Chronology”, 15-30. 
głównych szkół uczonych reprezentujących odmienne stanowiska w tym zakresie ${ }^{8}$. Tradycyjna chronologia epoki żelaza silnie wiąże się z przekazem biblijnym i obecnie jest nazywana chronologią ,konwencjonalną" lub ,wysoką" ze względu na przyjmowanie stosunkowo starożytnej datacji ${ }^{9}$. W ostatnich dziesięcioleciach uczeni przyjmujący w kwestii historyczności przekazu biblijnego bardziej krytyczne stanowisko („minimaliści”) zaproponowali „niską” chronologię ${ }^{10}$, która jest późniejsza w stosunku do tradycyjnej, niekiedy nawet o niemal sto lat. Odpowiedzią konserwatystów („maksymalistów”) było ustalenie zmodyfikowanej chronologii konwencjonalnej (The Modified Conventional Chronology) ${ }^{11}$.

Współcześni konserwatyści nawiązują do tradycyjnej archeologii biblijnej, której celem od lat dwudziestych XX wieku było przeciwstawianie się krytycznym teoriom i udowodnienie, że historia

8 Najważniejsze metody określania chronologii bezwzględnej obejmują dziś datowanie radiowęglowe oraz datowanie metodą optycznie stymulowanej luminescencji (OSL). Problemem jest to, że obydwie metody - zwłaszcza datowanie radiowęglowe - dają zazwyczaj wyniki przybliżone, nawet do kilku dekad, które w przypadku historii biblijnej mogą prowadzić do zupełnie różnych rekonstrukcji historycznych. Na przykład w odniesieniu do pałaców z epoki żelaza IIA w Megiddo różnica 70-80 lat (ok. 940 a 860 przed Chr.) powoduje zupełnie inne datowanie albo odnoszące się do Zjednoczonego Królestwa, albo do okresu panowania dynastii Omrydów z Królestwa Izraela. Żeby otrzymać wiarygodne wyniki datowania radiowęglowego, należy postępować ściśle według określonych zasad przyjętych przez profesjonalistów, np. ze względu na wysoką wiarygodność należy datować przede wszystkim próbki krótkotrwałe (nasiona zbóż, pestki oliwek itp.). Zob. I. Finkelstein, „History of Ancient Israel”, 376-378.

9 A. Mazar, „The Iron Age Chronology Debate”, 105-111; tenże, Archaeology of the Land, 1990.

10 I. Finkelstein, E. Piasetzky, ,The Iron Age Chronology Debate”, 50-54.

11 A. Mazar, „The Search for David and Solomon”, 122. Zamieszczono tam tabelę zestawiającą konwencjonalną chronologię epoki żelaza ze zmodyfikowaną chronologią konwencjonalną. Por. również tenże, „The Iron Age Chronology Debate”, 105-111; Z. Herzog, L. Singer-Avitz, „Sub-Dividing the Iron Age IIA”, 163-195. Debatę na temat chronologii ,niskiej” i ,wysokiej” przedstawił I. Finkelstein, „A Low Chronology Update”, 31-42. Autor uzasadnia tam swoje stanowisko - prof. Finkelstein, który kieruje ekspedycją prowadzącą badania w Megiddo, uważa się za „centrystę” i jest od lat zwolennikiem chronologii „,niskiej”, dla której kluczową, choć oczywiście nie wyłączną, metodą datowania jest datowanie radiowęglowe. 
biblijna jest dokładnym opisem przeszłości ${ }^{12}$. Izraelscy archeolodzy, przede wszystkim Yigael Yadin ${ }^{13}$, dołączyli do tej grupy uczonych w latach pięćdziesiątych. Konserwatywna archeologia biblijna dominowała przez większość XX wieku, jednak od lat siedemdziesiątych, a zwłaszcza w XXI wieku, coraz silniejszy staje się nurt badaczy krytycznych wobec konserwatyzmu. Ci tzw. „minimaliści” są przeciwni tradycyjnemu użyciu archeologii jako narzędzia w rekonstrukcji historii starożytnego Izraela w epoce żelaza i są orędownikami poglądu, że teksty biblijne nawiązujące do historii starożytnego Izraela zostały skompilowane w okresach perskim i hellenistycznym, a tym samym nie mają żadnej wartości dla zrozumienia wcześniejszych okresów $^{14}$. Ich poglądy krytykowane są przez „maksymalistów”15. Równolegle do „minimalistów” rozwija się w dzisiejszej archeologii biblijnej szkoła, której zwolenników można określić jako „centrystów". Uczeni należący do tej grupy również bazują na krytycznym podejściu do tekstu Biblii i archeologii, ale różnią się od „minimalistów" przyjętą argumentacją opartą na założeniu, że znaczna liczba tekstów biblijnych pochodzi z czasów późnomonarchicznych, a relacje, które zostały zapisane w Biblii, zawierają tradycje odzwierciedlające rzeczywistość w epoce żelaza, nawet jeśli ich kompilacja nastąpiła w okresach perskim i hellenistycznym ${ }^{16}$.

Dodać w tym miejscu wypada, że znaczna większość wyników datowania radiowęglowego próbek pobranych z różnych stanowisk związanych z archeologią biblijną zdaje się potwierdzać chronologię ,niską"17.

12 Przede wszystkim W.F. Albright, Archeologia Palestyny.

13 Y. Yadin, „Solomon's City Wall”, 80-86; tenże, „New Light on Solomon's Megiddo", 62-68.

14 I. Finkelstein, „History of Ancient Israel”, 372; P.L. Davies, In Search of Ancient Israel; T.L. Thompson, The Mythic Past.

15 Y. Garfinkel, ,The Birth and Death”, 46-53.

16 I. Finkelstein, History of Ancient Israel, 372; M. Liverani, Nie tylko Biblia; E.A. Knauf, Data and Debates. Zestawienie argumentacji związanej z „wysoką” $\mathrm{i}$,niską” chronologią prezentuje w swym podręczniku K.L. Noll, Canaan and Israel in Antiquity. Dobre wprowadzenie (wraz z najważniejszą literaturą) w ten problem znaleźć można również w tekście N.P. Lemche, The Same Old Story, 84-95.

17 Zob. T.E. Levy, T. Higham (red.). The Bible and Radiocarbon Dating; K.L. Noll, Canaan and Israel in Antiquity, 253. 


\section{Stratyfikacja epoki żelaza w Megiddo}

Datowanie i interpretowanie odkryć dokonanych w Megiddo przez badaczy reprezentujących wszystkie wspomniane wyżej szkoły, prowadzi ich do odmiennych wniosków, które odnoszą się do różnych etapów w dziejach miasta. To z kolei rodzi wiele kontrowersji związanych głównie z dylematem, czy archeologia potwierdza (w jakim stopniu?) przekaz biblijny, czy też mu zaprzecza. Dzieje się tak ze względu na znaczenie Megiddo dla archeologii biblijnej - pozostałości licznych odkrytych tutaj budowli, pochodzących z różnych epok, od dawna budzą szerokie zainteresowanie, które nie ogranicza się tylko do kręgów uczonych biblistów i archeologów.

Informacje zawarte w Tabeli 1 wskazują, do jak różnych wniosków dojść można w kwestii sekwencji wydarzeń w długiej i skomplikowanej historii tego miasta w zależności od tego, czy za właściwą uzna się tradycyjną, ,wysoką” chronologię, czy przyjmie się argumentację wskazywaną przez „minimalistów” oraz „centrystów”.

Tab. 1. Zestawienie stratyfikacji epoki żelaza w Megiddo z uwzględnieniem „wysokiej" i „niskiej” chronologii, dokonane przez Johannesa Nussbauma (daty przed Chr.) ${ }^{\mathrm{A}}$

\begin{tabular}{|c|c|c|c|c|}
\hline Warstwa & $\begin{array}{l}\text { Typologia } \\
\text { ceramiki }\end{array}$ & $\begin{array}{l}\text { Wysoka } \\
\text { chronologia }\end{array}$ & $\begin{array}{c}\text { Niska } \\
\text { chronologia }\end{array}$ & Charakter osadnictwa \\
\hline III & żelazo IIC & $\begin{array}{l}\text { okres asyryj- } \\
\text { ski }(732-625)\end{array}$ & $\begin{array}{l}\text { okres asyryj- } \\
\text { ski }(732-625)\end{array}$ & $\begin{array}{l}\text { nowy plan miasta } \\
\text { w układzie ortogonalnym }\end{array}$ \\
\hline IVA & żelazo IIB & $\begin{array}{l}\text { Północne } \\
\text { Królestwo } \\
\text { (IX-VIII w.) } \\
\text { zlikwido- } \\
\text { wane przez } \\
\text { Asyryjczyków }\end{array}$ & $\begin{array}{l}\text { miasto zbu- } \\
\text { dowane przez } \\
\text { króla Joasza } \\
\text { lub Jeroboama } \\
\text { II w VIII w. } \\
\text { po trwają- } \\
\text { cym jakiś } \\
\text { czas okresie } \\
\text { niezamieszka- } \\
\text { nia, zlikwi- } \\
\text { dowane przez } \\
\text { Asyryjczyków }\end{array}$ & $\begin{array}{l}\text { poprzednie miasto } \\
\text { z miejscami kultu } \\
\text { i pałacami zostało } \\
\text { przekształcone w miasto } \\
\text { garnizonowe, obro- } \\
\text { bione bloki kamienne } \\
\text { pochodzące z pałaców } \\
\text { z warstw VA-IVB po- } \\
\text { nownie zostały wykorzy- } \\
\text { stane przy wznoszeniu } \\
\text { innych budowli }\end{array}$ \\
\hline
\end{tabular}




\begin{tabular}{|c|c|c|c|c|}
\hline Warstwa & $\begin{array}{l}\text { Typologia } \\
\text { ceramiki }\end{array}$ & $\begin{array}{c}\text { Wysoka } \\
\text { chronologia }\end{array}$ & $\begin{array}{c}\text { Niska } \\
\text { chronologia }\end{array}$ & Charakter osadnictwa \\
\hline VA-IVB & $\begin{array}{l}\text { późne } \\
\text { żelazo IIA }\end{array}$ & $\begin{array}{l}\text { zjednoczona } \\
\text { monar- } \\
\text { chia (lata } \\
\text { 1000-925) } \\
\text { zniszczona } \\
\text { przez faraona } \\
\text { Szeszonka } \\
\text { w } 925 \mathrm{r} \text {. }\end{array}$ & $\begin{array}{l}\text { lata 887-840: } \\
\text { dynastia } \\
\text { Omrydów } \\
\text { (królestwo } \\
\text { Izraela), po- } \\
\text { konana przez } \\
\text { króla Hazaela } \\
\text { z Damaszku }\end{array}$ & $\begin{array}{l}\text { ważny ośrodek miejski } \\
\text { z pałacami i kilkoma } \\
\text { miejscami kultu, z wi- } \\
\text { docznymi wpływami } \\
\text { fenickimi i syryjskimi, } \\
\text { zniszczony przez gwał- } \\
\text { towny pożar }\end{array}$ \\
\hline VB & $\begin{array}{l}\text { wczesne } \\
\text { żelazo IIA }\end{array}$ & & & lokalna osada \\
\hline VIA & $\begin{array}{l}\text { późne } \\
\text { żelazo I }\end{array}$ & $\begin{array}{l}\text { warstwa dato- } \\
\text { wana na lata } \\
1200-1000, \\
\text { której znisz- } \\
\text { czenie łączy } \\
\text { się z podbojem } \\
\text { Dawida }\end{array}$ & $\begin{array}{l}\text { warstwa dato- } \\
\text { wana na lata } \\
1130-950, \text { któ- } \\
\text { rej zniszczenie } \\
\text { przypisuje } \\
\text { się faraonowi } \\
\text { Szeszonkowi } \\
\text { I w } 925 \text { r. }\end{array}$ & $\begin{array}{l}\text { bogate i duże miasto (ka- } \\
\text { nanejskie) z budynkami } \\
\text { wzniesionymi z cha- } \\
\text { rakterystycznej cegły, } \\
\text { ale bez monumentalnej } \\
\text { architektury na wielką } \\
\text { skalę, zniszczone przez } \\
\text { gwałtowny pożar }\end{array}$ \\
\hline VIB & $\begin{array}{l}\text { wczesne } \\
\text { żelazo I }\end{array}$ & & & lokalna osada \\
\hline
\end{tabular}

A J. Nussbaum, Stratigraphic Discussion of the "Solomonic" City Gate at Megiddo. Autor opiera się na następujących publikacjach: A. Mazar, „The Debate over the Chronology", 24; A. Zarzecki-Peleg, Yadin's Expedition to Megiddo, 330; I. Finkelstein, E. Piasetzky, „The Iron Age Chronology Debate”, 50; Y. Shiloh, „Solomon's Gate at Megiddo" as Recorded by its Excavator, R. Lamon”, 69; D. Ussishkin, „Was the 'Solomonic' City Gate”, 6-7. 


\section{Stajnie Salomona?}

Do najbardziej dyskusyjnych zagadnień związanych z chronologią epoki żelaza w Megiddo od kilkudziesięciu lat należy datowanie dwóch obiektów: tzw. „stajni Salomona” oraz tzw. „bramy Salomona” (brama 2156). Pierwszy z tych obiektów odkryli w latach dwudziestych ubiegłego wieku amerykańscy archeolodzy z Instytutu Orientalistyki Uniwersytetu Chicago, a kierujący ekspedycją Philip L.O. Guy doszedł do wniosku, że są to stajnie króla Salomona. Uczony oparł swoją identyfikację na biblijnych wzmiankach związanych z zakrojoną na szeroką skalę działalnością budowlaną i strategiczną tego władcy: „Tak się zaś miała rzecz z pańszczyzną, jaką wprowadził król Salomon, budując przybytek Pana i swój pałac, i twierdzę Millo, i mury Jeruzalemu, i warownie Hazor, Megiddo i Gezer" (1 Krl 9,15), „Także wszystkie miasta ze spichlerzami, jakie Salomon posiadał, i miasta dla wozów, i miasta dla konnicy” (1 Krl 9,19) oraz „I nagromadził Salomon wozów i jezdnych tak, iż miał tysiąc czterysta wozów wojennych i dwanaście tysięcy jezdnych, a rozmieścił je po miastach przeznaczonych dla wozów oraz przy osobie króla w Jeruzalemie" (1 Krl 10,26). Teoria ta spotkała się z powszechną akceptacją i pozostała standardowym wyjaśnieniem funkcji tych obiektów w Megiddo przez następnych kilkadziesiąt lat ${ }^{18}$.

We wczesnych latach siedemdziesiątych XX wieku Yigael Yadin, $\operatorname{archeolog} \mathrm{z}$ Uniwersytetu Hebrajskiego w Jerozolimie, przeprowadził na tym stanowisku serię niewielkich prac wykopaliskowych, w wyniku których podtrzymał identyfikację tych obiektów jako stajni. Przesunął jednak ich datowanie na IX wiek przed Chr., w konsekwencji czego zaczęto nazywać je ,stajniami Achaba”19. Wykopaliska w obszarze stajni północnych (obszar L) wznowiła w 1998 r. ekspedycja Uniwersytetu w Tel Awiwie. Na podstawie analizy ceramiki, a także datowania radiowęglowego próbek krótkotrwałych powiązano te obiekty z warstwą IV datowaną na początek VIII w. przed Chr., co oznaczało ostrożne przypisanie ich panowaniu Jeroboama $\mathrm{II}^{20}$.

18 P.L.O. Guy, New Light from Armageddon, 37-48; D.O. Cantrell, I. Finkelstein, „A Kingdom for a Horse”, 643.

19 Y. Yadin, ,The Megiddo Stables”, 249-52.

20 N. Franklin, „Entering the Arena”, 87. 
Co ciekawe, okazało się, że - oprócz kompleksu stajni północnych (obiekty 364, 401, 407 oraz powiązany z nimi budynek 338 ${ }^{21}$ ) - do warstwy IV przynależy także podobny kompleks stajni południowych (m.in. obiekty 1483-1612), a łączny obszar obydwu tych kompleksów obejmuje prawie połowę istniejącego wówczas miasta ${ }^{22}$.

Rozległe, wyposażone w obszerne dziedzińce kompleksy stajni w Megiddo były zdecydowanie bardziej monumentalne niż budynki o podobnym przeznaczeniu, których pozostałości odkryto na innych stanowiskach archeologicznych. Ich unikalne i niezwykłe cechy wskazują, że architektura całego miasta warstwy IV wydaje się podporządkowana funkcji tych budynków ${ }^{23}$. Część badaczy uważa, że Megiddo było wówczas obozem wojskowym dobrze wyposażonym w stajnie dla koni, które służyły w korpusie rydwanów Północnego Królestwa $^{24}$. Ciekawą alternatywą dla tej propozycji jest sugestia, że stajnie Megiddo były wykorzystywane jako ośrodek szkoleniowy dla koni sprowadzanych z Egiptu, sprzedawanych następnie (po przeszkoleniu do użycia ich w zaprzęgu rydwanu) do Asyrii i innych krajów sąsiadujących z Królestwem Izraela ${ }^{25}$. Takie wyszkolone konie były bardzo drogim towarem i Północne Królestwo, a w szczególności Megiddo, mogło być istotnym ogniwem w handlu nimi. Wielkie imperium asyryjskie potrzebowało zwłaszcza dużych koni kuszyckich sprowadzanych z Egiptu i doskonałych do rydwanów. Ponieważ Megiddo znajdowało się na międzynarodowym szlaku handlowym Via Maris, nietrudno sobie wyobrazić, że kupcy asyryjscy mogli korzystać z pośrednictwa tego miasta w pozyskiwaniu koni. Tak ujęła to izraelska badaczka Norma Franklin: ,„przekształcenie

21 Być może było to główne centrum administracyjne miasta. Zob. A. Kleiman, I. Finkelstein, „The Date of Building 338”, 50-55.

22 N. Franklin, ,Megiddo's Stables”, 7.

23 D.O. Cantrell, I. Finkelstein, „A Kingdom for a Horse”, 643.

24 Tak np. D. Ussishkin, Megiddo - Armageddon, 399-418.

25 D.O. Cantrell, I. Finkelstein, „A Kingdom for a Horse”, 656 i nast.; I. Finkelstein, The Forgotten Kingdom, 135; E.A. Knauf, P. Guillaume, A History of Biblical Israel, 76; M. Liverani, Nie tylko Biblia, 138. 
Megiddo w ośrodek szkolenia koni i handlu było ekonomicznie korzystne zarówno dla Izraela, jak i Asyrii”26.

\section{Wnioski}

Odkrycia archeologiczne uzupełnione badaniami nad tekstami asyryjskimi pozwalają przypuszczać, że Megiddo warstwy IV było znaczącym ośrodkiem wojskowym i handlowym, większym od innych współczesnych mu miast w Północnym Izraelu. Było to miasto wzniesione przez Jeroboama II, zapewne za wiedzą i zgodą Asyrii. Trudno dziś nadal utrzymywać, że stajnie, które wówczas zbudowano, należy łączyć z panowaniem Salomona, jak twierdzili ich odkrywcy i kolejni archeolodzy. Bardziej prawdopodobne jest, że powstały one jakieś dwieście lat po okresie, który chronologia biblijna wiąże z Salomonem. Mimo to część badaczy, a także osób nie zajmujących się profesjonalnie archeologią czy biblistyką nadal jest zdania, że wielkie kompleksy stajni w Megiddo zbudowano na polecenie tego króla ${ }^{27}$.

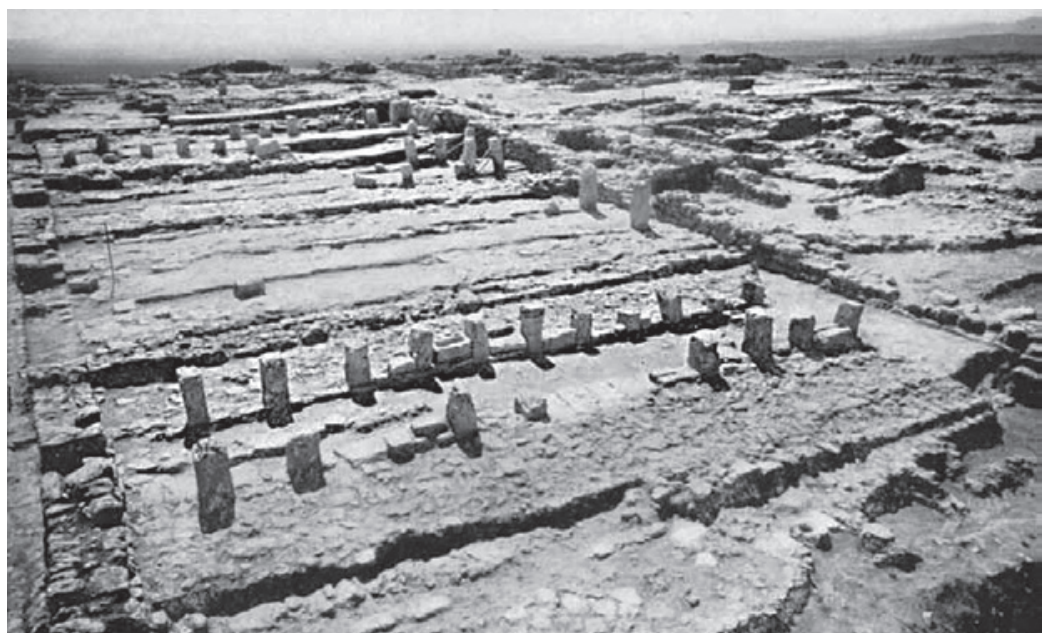

Ryc. 1. Stajnie 364 (źródło: R.S. Lamon, G.M. Shipton, Megiddo I, fig. 51)

26 N. Franklin, „Megiddo's Stables”, 10: „transforming Megiddo into a horse training and trading center was economically beneficial to both Israel and Assyria".

27 Zob. np. J. Green, „Model of 'King Solomon's Stables”, 161-164. 


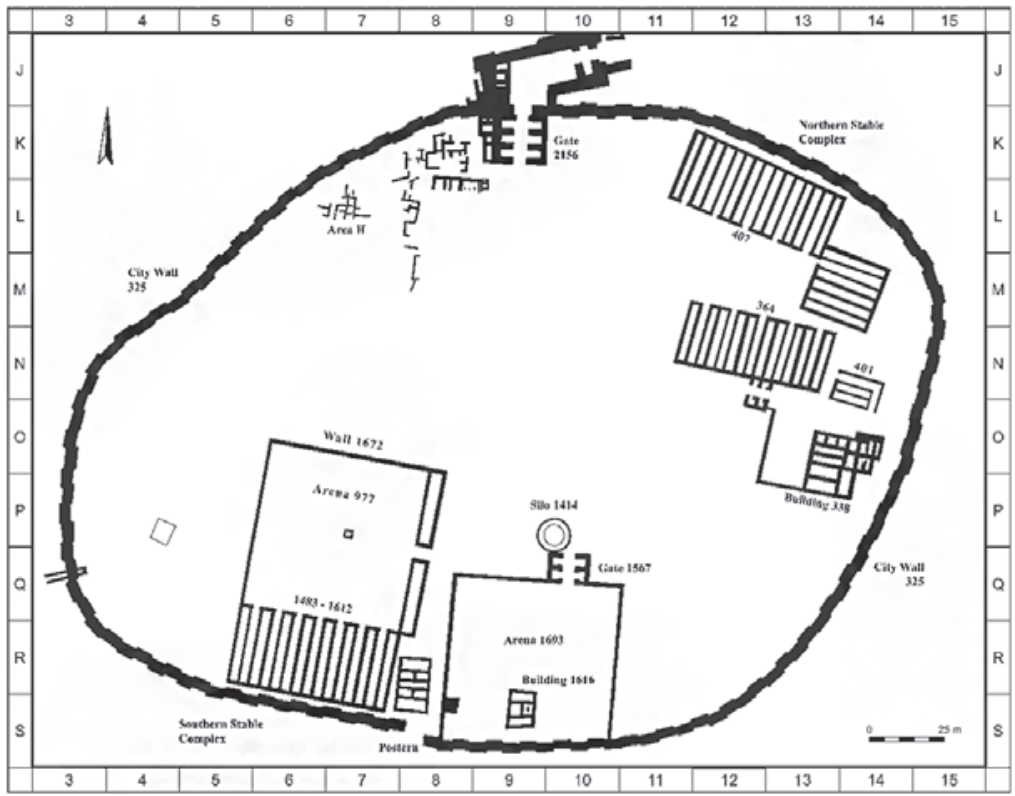

Ryc. 2. Plan Megiddo - miasto warstwy IV (źródło: N. Franklin, „Entering the Arena", 88)

\section{Brama Salomona?}

Drugi interesujący nas obiekt - „brama Salomona” - należy do sekwencji czterech bram pochodzących z epoki żelaza, zbudowanych jedna na drugiej, także odkrytych przez ekspedycję Uniwersytetu Chicago w latach dwudziestych i trzydziestych XX wieku ${ }^{28}$. Trzy spośród tych bram należą do najbardziej dyskusyjnych zabytków epoki żelaza na obszarze Lewantu. Trwające dziesiątki lat spory dotyczyły ich detali architektonicznych, powiązań (lub ich braku) z murami obronnymi, przynależności stratygraficznej, dat względnych i bezwzględnych oraz możliwych powiązań biblijnych. Ale

28 R.S. Lamon, G.M. Shipton, Megiddo I. Seasons of 1925-34 Strata I-V, 74-83 oraz G. Loud, Megiddo II. Seasons of 1935-39, 46-57. 
od samego początku debatę zdominowały kontrowersje wokół tzw. „bramy Salomona” (obiekt 2156) ${ }^{29}$.

Jednym z najbardziej wpływowych uczonych, przekonanych o tym, że bramę tę należy powiązać z działalnością budowlaną Salomona, był Yigael Yadin. W latach pięćdziesiątych XX wieku uczony ten prowadził wykopaliska w Hazor (miasto wzmiankowane obok Megiddo i Gezer we wspomnianym już fragmencie $1 \mathrm{Krl}$ 9,15), gdzie jego zespół dokonał odkrycia dużej, sześciokomorowej bramy miejskiej, łudząco podobnej do obiektu 2156 z Megiddo. Dostrzegłszy to podobieństwo, Yadin uznał, że stanowi ono dowód potwierdzający prawdziwość przekazu biblijnego z 1 Księgi Królewskiej. Jego teoria opierała się na trzech filarach: stratygrafii, chronologii i Biblii. W 1970 roku tak o niej pisał: „Nasza decyzja o przypisaniu tej warstwy Salomonowi była oparta przede wszystkim na fragmencie 1 Księgi Królewskiej, stratygrafii i ceramice. Ale kiedy dodatkowo znaleźliśmy w tej warstwie sześciokomorową bramę z dwiema wieżami, połączoną z murem kazamatowym, identyczną w rzucie i rozmiarze $\mathrm{z}$ bramą w Megiddo, byliśmy pewni, że udało nam się zidentyfikować miasto Salomona" ${ }^{30}$. Teorię tę przyjęto niemal za pewnik, chociaż argumentację Yadina skrytykował już Aharoni w 1972 roku, a po ukazaniu się w 1980 roku artykułu Ussishkina, teoria Yadina stopniowo traciła akceptację $e^{31}$.

29 I. Finkelstein, M.J. Adams, E. Hall, E. Levy, „The Iron Age Gates of Megiddo”, 167. Spośród bardzo obszernej dyskusji na temat tej bramy podaję wybrane publikacje: Y. Yadin, „Megiddo of the Kings of Israel”, 66-96; tenże, Hazor with a Chapter on Israelite Megiddo, 158-161; Y. Aharoni, „The Stratification of Israelite Megiddo”, 302-311; Y. Shiloh,. ,Solomon's Gate at Megiddo”, 69-76; D. Ussishkin, „Was the 'Solomonic' City Gate”, 1-18; tenże, Megiddo - Armageddon, 333-336, 389-399; Z. Herzog, Das Stadttor in Israel, 93-108; A. Kempinski, Megiddo: A City-State, 113-114; E. Stern, „Hazor, Dor and Megiddo”, 12-30.

30 Y. Yadin, „Megiddo of the Kings of Israel”, 67: „Our decision to attribute that layer to Solomon was based primarily on the 1 Kings passage, the stratigraphy and the pottery. But when in addition we found in that stratum a six-chambered, twotowered gate connected to a casemate wall identical in plan and measurement with the gate at Megiddo, we felt sure we had successfully identified Solomon's city”. Zob. I. Finkelstein, „A Low Chronology Update”, 34.

31 Y. Aharoni, ,The Stratification of Israelite Megiddo”, 302-311; D. Ussishkin, „Was the 'Solomonic' City Gate”, 1-18. 
Kwestionujący propozycje tego uczonego badacze wskazywali na przykład, że bramy w Hazor, Gezer i Megiddo należały do odmiennych typów fortyfikacji (dwa pierwsze miasta obwarowane były murem kazamatowym, a Megiddo miało mur obronny innego typu) ${ }^{32}$. Problemem była też chronologia - David Ussishkin udowodnił, że brama 2156 z Megiddo powstała później niż bramy w Hazor i w Ge$z^{3}{ }^{33}$. Podobne bramy odkryto także w położonym na Szefeli Lakisz (z IX w. przed Chr.), w filistyńskim Aszdod (z VIII w. przed Chr.), a nawet w Moabie (sześciokomorowa brama w Jahaz, datowana na IX w. przed Chr., była mniejsza niż podobne obiekty w Hazor i Gezer $^{34}$ ), co pokazuje, że mamy raczej do czynienia z pewnym stylem architektonicznym utrzymującym się przez kilka stuleci i mającym lokalne odmiany, a nie z działalnością budowlaną jednego monarchy $^{35}$. Kolejne znaleziska ceramiki, pozostałości budowli pałacowych czy obronnych (m.in. w Jizreel ${ }^{36}$ i w Samarii ${ }^{37}$ ) z czasów panowania Omrydów w Północnym Królestwie wykazały podobieństwo do zabytków pochodzących z Megiddo, co pozwoliło uściślić chronologię spornej bramy 2156 i powiązać ją z panowaniem władców Królestwa Izraela w tym mieście. Tradycyjne datowanie podważyły również zakrojone na szeroką skalę badania z wykorzystaniem metody węgla radioaktywnego, w których przeanalizowano próbki pochodzące z warstw kojarzonych dotychczas z panowaniem Dawida i Salomona, pobrane z licznych stanowisk archeologicznych (m.in. Dor, Tel Rehov, Tel Hadar, Hazor, Megiddo). Wywołało to wielką debatę między zwolennikami „niskiej” i „,wysokiej” chronologii ${ }^{38}$.

32 I. Finkelstein, N.A. Silberman, Dawid i Salomon, 215.

33 D. Ussishkin, „Area G. Soundings”, 104-122; tenże, „Notes on Megiddo, Gezer, Ashdod", 71-91.

34 I. Finkelstein, The Forgotten Kingdom, 99.

35 K.L. Noll, Canaan and Israel in Antiquity, 244.

36 D. Ussishkin, Megiddo - Armageddon, 324.

37 M. Liverani, Nie tylko Biblia, 137-140; N. Franklin, ,Correlation and Chronology", 310-322.

38 Spośród licznych prac wymienię tu przykładowo: E. Boaretto, A.J.T. Jull, A. Gilboa, I. Sharon, „,Dating the Iron age I/II”; M.B. Toffolo, E. Arie, M.A.S. Martin, E. Boaretto, I. Finkelstein, „Absolute Chronology of Megiddo”. 
Warto w tym miejscu dodać, że jedynego niewielkiego badania kontrolnego w obrębie bramy 2156 w Megiddo od czasu jej odkrycia dokonał Yadin w 1967 roku $^{39}$ i od tej pory nie podjęto tam żadnych prac terenowych aż do sezonu 2018, gdy wykopaliska prowadzone w tym obszarze przez zespół Uniwersytetu w Tel Awiwie rzuciły nowe światło na dotychczasowe kwestie sporne i wydają się rozstrzygać większość wcześniejszych dylematów ${ }^{40}$.

\section{Rezultaty najnowszych prac wykopaliskowych w rejonie tzw. „bramy Salomona”}

W momencie rozpoczęcia badań w 2018 roku archeolodzy wskazywali, że ich celem jest przede wszystkim wyjaśnienie następujących problemów: przypisanie stratygraficzne bramy 2156 do warstw VA-IVB lub IVA, lokalizacja podłoża bramy 2156 oraz przypisanie stratygraficzne odpływu, który przechodzi w przestrzeni między dwoma skrzydłami zarówno bramy 3165, jak i bramy 2156, a także określenie liczby i przynależności stratygraficznej bram zbudowanych i użytkowanych powyżej bramy $2156^{41}$.

Badaniom poddano skrzydło wschodnie obiektu 2156 (znajduje się ono nadal in situ wraz z kamiennym wypełnieniem centralnej komory), a także część wschodnich skrzydeł dwóch faz bramy 500b, wzniesionej powyżej obiektu 2156. Jest to nowy obszar badań określony jako Area Z. Miejsca te przedstawiono na ryc. 3 z odpowiednimi podpisami.

39 Y. Yadin, „Megiddo of the Kings of Israel”, 86.

40 Raport z tych prac zawiera publikacja I. Finkelstein, M.J. Adams, E. Hall, E. Levy, „The Iron Age Gates of Megiddo”.

41 I. Finkelstein, M.J. Adams, E. Hall, E. Levy, „The Iron Age Gates of Megiddo", 173. 


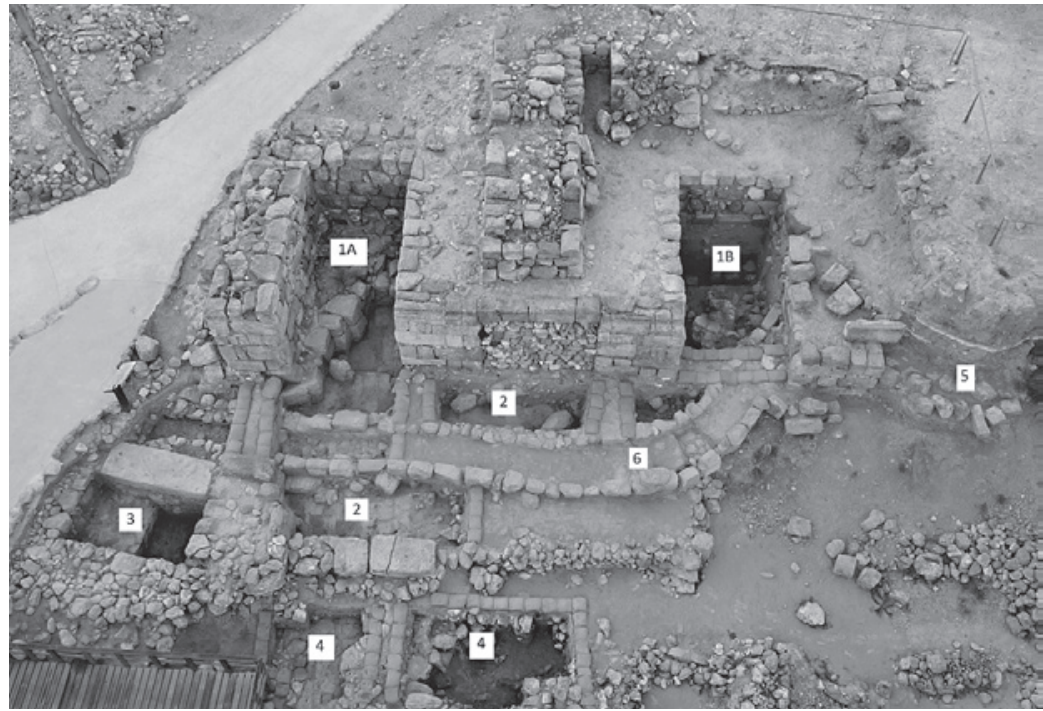

Ryc. 3. Lokalizacja miejsc objętych badaniami w sezonie 2018 (Obszar Z). 1A, 1B dwie z trzech komór (północna i południowa) wschodniego skrzydła bramy 2156; 2 - wewnętrzny plac bramy 3165; 3-zachodnia komora bramy 3165; 4-teren pierwotnie pod zachodnim (obecnie nieistniejącym) skrzydłem bramy 2156; 5 - elementy łączące się z bramą 2156 i bramą nad nią (źródło: fotografia dzięki uprzejmości Megiddo Expedition ${ }^{42}$ )

Konkluzje przyjęte przez archeologów po zakończeniu badań w sezonie 2018 przedstawiają się następująco:

1. Brama 3165 została zbudowana $w$ warstwie VIA i została zniszczona wraz $\mathrm{z}$ resztą miasta $\mathrm{w}$ wielkim pożarze datowanym na X wiek przed Chr. (lata 985-935); spalone cegły znaleziono in situ i są one nadal widoczne wewnątrz i pod północno-wschodnią komorą bramy 2156, podobne zniszczenia zachowały się w tej warstwie w innych częściach tellu.

2. Kiedy Megiddo zostało ponownie zamieszkane po zniszczeniu (warstwa VB), było nieufortyfikowaną osadą pozbawioną bramy.

3. Brama 2156 jest zbudowana tuż nad ruinami bramy warstwy VIA (3165) w warstwie VA-IVB.

42 I. Finkelstein, M.J. Adams, E. Hall, E. Levy, „The Iron Age Gates of Megiddo", 175. 
4. Miasto warstwy VA-IVB zostało częściowo zniszczone pod koniec epoki żelaza IIA; zniszczenie to zapewne związane jest z atakiem Aramejczyków na Królestwo Północne na początku drugiej połowy IX wieku przed Chr. (przez władcę Damaszku Hazaela $^{43}$ ), po czym mógł nastąpić kilkudziesięcioletni okres bez osadnictwa (koniec IX wieku).

5. W tym okresie, poniżej warstwy IVA, brama 2156 była wolnostojąca, bez muru miejskiego (mogła pełnić funkcję ceremonialnego wejścia do miasta).

6. Kiedy miasto odzyskało siły we wczesnej fazie warstwy IVA (prawdopodobnie na początku VIII wieku przed Chr.), zostało natychmiast ufortyfikowane murem miejskim 325, który został połączony ze starą bramą 2156.

7. Do miasta warstwy IVA (ok. 800-732 przed Chr.) należy brama 500b; w celu budowy tej nowej bramy komory obiektu 2156 wypełniono kamieniami i przykryto ziemią, co stanowiło solidny fundament nowej budowli (dlatego brama 2156 tak dobrze się zachowała: od VIII wieku przed Chr. do odkrycia w latach trzydziestych XX wieku znajdowała się w nienaruszonym stanie).

8. Domysłem pozostaje, dlaczego starą bramę 2156 zastąpiono nową (500b); warto zauważyć, że nowa brama została zbudowana współcześnie $\mathrm{z}$ dwoma kompleksami stajni, które zmieniły układ miasta: być może szersza brama z głębszymi komorami lepiej pasowała do nowych potrzeb miasta (była łatwiejsza do pokonania dla zaprzęgów konnych).

9. Miasto warstwy IVA zostało przejęte przez Tiglatpilesara III w 732 r. przed Chr., w związku z tym brama 500b mogła zostać wycofana z eksploatacji natychmiast lub nieco później, kiedy zmieniono układ urbanistyczny Megiddo ${ }^{44}$.

43 I. Finkelstein, The Forgotten Kingdom, 119 i nast.; M. Liverani, Nie tylko Biblia, 126.

44 I. Finkelstein, M.J. Adams, E. Hall, E. Levy, ,The Iron Age Gates of Megiddo", 175-190. 


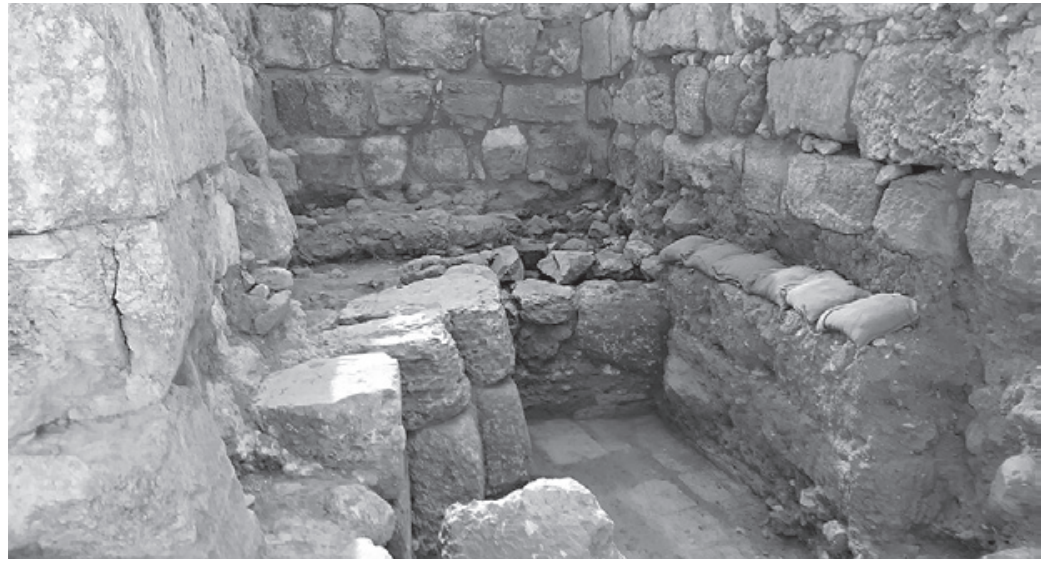

Ryc. 4. Wnętrze północno-wschodniej komory bramy 3165, pod kamienną ścianą bramy 2156; w głębi, w środkowej części fotografii widoczna warstwa spalonych cegieł in situ (źródło: fotografia własna autorki)

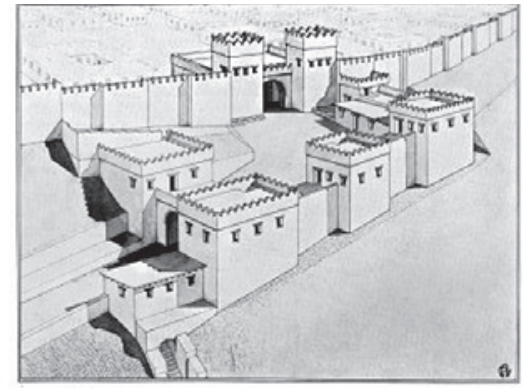

Ryc. 5. Rekonstrukcja kompleksu bramnego w Megiddo. Sześciokomorowa tzw. brama Salomona znajduje się u góry (źródło: G. Loud, Megiddo II, ryc. 107) 


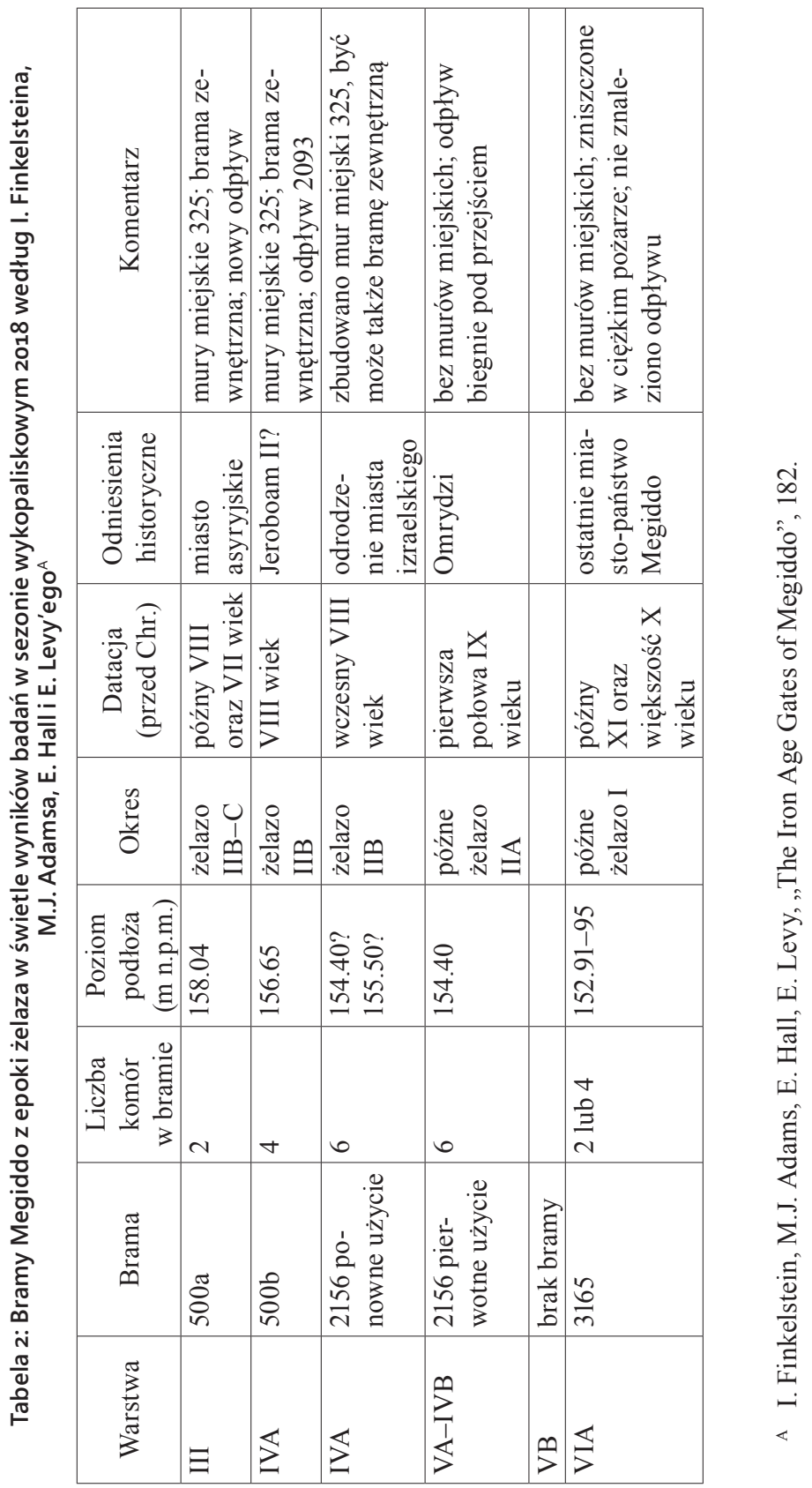


Na podstawie wyników ostatnich badań obszaru tzw. „bramy Salomona" w Megiddo można ją powiązać z warstwami VA-IVB oraz IVA, a jej budowę usytuować w mieście warstwy VA-IVB. Według przyjętej przez ekspedycję Uniwersytetu w Tel Awiwie „niskiej” chronologii zarówno wzniesienia, jak i użytkowania tej bramy nie należy więc wiązać z panowaniem Salomona, ale z okresem rządów Omrydów (i przynależnością Megiddo do Królestwa Izraela w pierwszej połowie IX w. przed Chr., w epoce późnego żelaza IIA) oraz z czasem odrodzenia miasta izraelskiego po przejściowej dominacji aramejskiej (wczesny VIII w., żelazo IIB). Natomiast zastosowanie chronologii „wysokiej”, która warstwy VA-IVB sytuuje w okresie Zjednoczonej Monarchii, oznaczałoby dopuszczenie możliwości, że sporna brama została zbudowana w okresie rządów Salomona. Mamy zatem do czynienia ze stanem rzeczy, w którym wyniki badań archeologicznych pomagają wprawdzie uporać się z problemem datowania, ale nie wskazują rozwiązań, które prowadziłyby do powszechnego konsensusu. Część badaczy nadal uważa, że fortyfikacje Hazor, Megiddo i Gezer, włącznie z ich bramami, można przypisać działalności Salomona. Stanowisko to podtrzymuje na przykład A. Mazar, choć w znacząco zmodyfikowanej formie w stosunku do wcześniejszych propozycji ${ }^{45}$.

\section{Wnioski}

Uwzględnienie zastosowanej metodologii badań (opartych na skrupulatnym rozpoznaniu stratyfikacji obszaru Z), a przede wszystkim najnowszych metod datowania radiowęglowego pozwala uznać propozycję archeologów z Uniwersytetu w Tel Awiwie za bardziej wiarygodną. Ten zespół uczonych prowadzi badania różnych obszarów w obrębie całego tellu w Megiddo od ponad dwudziestu lat, może zatem w budzących kontrowersje problemach zaproponować rozwiązanie uwzględniające szeroką perspektywę. Należy zatem przyjąć, że tzw. „brama Salomona” w Megiddo została zbudowana później

45 A. Mazar, „The Spade and the Text”, 143-171. Szerzej na ten temat: K.L. Noll, Canaan and Israel in Antiquity, 232. 
niż początkowo sądzono - w czasach Omrydów i była użytkowana za panowania ich następców w Królestwie Północnym.

Odrębną kwestią pozostaje ustalenie, dlaczego w roku jej odkrycia i w latach kolejnych uczeni przypisali jej budowę Salomonowi, podobnie jak to się stało w przypadku stajni, których pozostałości zachowały się w Megiddo. Z pewnością miało na to wpływ oparcie się badaczy na biblijnych wzmiankach związanych z zakrojoną na szeroką skalę działalnością budowlaną i strategiczną tego władcy (1 Krl 9,15; 9,19; 10,26), które uznali za historyczny przekaz zawierający informację o prawdziwych wydarzeniach. Księgi Królewskie nie powinny być jednak traktowane tak, jakby były obiektywnym zapisem wydarzeń - nie stanowią one bowiem historiografii w greckim czy też współczesnym tego słowa znaczeniu, ale przedstawiają raczej nacechowaną ideologicznie interpretację historii Izraela i Judy ${ }^{46}$. Celem autorów biblijnych nie było w istocie naukowe badanie przeszłości, ale - jak to ujął Ł. Niesiołowski-Spanò - formowanie teologii i legitymizacja systemu wartości, sposobu sprawowania władzy i ustalanie świadomości narodowej ${ }^{47}$. Dlatego autorzy biblijni, wykorzystując wiedzę o prawdziwych wydarzeniach, swobodnie kształtowali opis przeszłości bez przywiązywania szczególnej wagi do wiernego odzwierciedlenia rzeczywistości.

\section{Dlaczego Salomon?}

Dla zrozumienia powstania koncepcji Izraela jako całego narodu kluczowe są dwa zawarte w Biblii opowiadania: historia Dawida (1 Sm

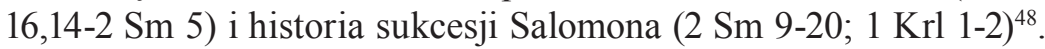
Dlatego postaci obydwu tych władców obarczone są tak olbrzymim

46 E.A. Knauf, 1 - 2 Rois, 390; K.L. Noll, Canaan and Israel in Antiquity, 80, 95, 83, gdzie autor zwraca uwagę, że starożytny język hebrajski nie posiada odpowiednika greckiego słowa historia.

47 Ł. Niesiołowski-Spanò, Mityczne początki miejsc, 25; por. podobnie w odniesieniu do innych ksiąg biblijnych M. Majewski, Pięcioksiąg odczytany na nowo, 59: „Redakcja Pięcioksięgu okazuje się procesem, w którym brali udział oryginalni autorzy i pisarze, którzy nie wahali się poprawiać, interpretować czy zmieniać kształt i wymowę starszych tradycji, jak i tworzyć zupełnie od nowa".

48 I. Finkelstein, The Forgotten Kingdom, 155. 
ładunkiem emocjonalnym, który znajduje swoje odzwierciedlenie także we współczesnym dyskursie naukowym. Sylwetka Salomona jest przedmiotem licznych kontrowersji, którymi tutaj nie będziemy się zajmować ${ }^{49}$, jednak w kontekście powiązania postaci tego króla z wynikami badań archeologicznych należy zwrócić uwagę na kilka kwestii. Informacje zawarte w Biblii na jego temat są z pewnością wynikiem późniejszych redakcji. Niosą one ze sobą połączenie znaczeń politycznych (władca Zjednoczonego Królestwa) i religijnych (budowa Pierwszej Świątyni w Jerozolimie).

Dziś rozważa się co najmniej dwa zasadnicze scenariusze związane z panowaniem Salomona: pierwszy zakłada, że był władcą wielkiego królestwa obejmującego obszar od Negewu do Górnej Galilei ${ }^{50}$, a nawet od Eufratu do granicy z Egiptem, drugi - że jego królestwo nie miało większych rozmiarów i pokrywało się ze skromnym władztwem Dawida oraz przechodziło kryzys władzy ${ }^{51}$. Pojawiają się także głosy negujące historyczność tego króla w ogóle, które wskazują na brak jakiejkolwiek wzmianki o nim w źródłach pozabiblijnych ${ }^{52}$. Zwraca się również uwagę na możliwość przypisania Salomonowi dążenia do objęcia władzy na terytoriach północnych, które w rzeczywistości miało miejsce za panowania w Judzie króla Jozjasza ${ }^{53}$. Zrodziła się też hipoteza, według której opis imperium Salomona

49 Przedstawił je chociażby I. Finkelstein w książce Dawid i Salomon.

50 Wskazuje się, że wyrażenie biblijne ,od Dan do Beer Szeby” nie odzwierciedla realnego kształtu żadnego z państw, ale reprezentuje raczej panizraelską ideę, o politycznym i religijnym charakterze, nigdy w rzeczywistości nie zrealizowaną; co ciekawe, żadnego z tych położonych na obrzeżach miast przekaz biblijny nie łączy z działalnością budowlaną (obejmującą także wznoszenie fortyfikacji) Salomona; zob. K.L. Noll, Canaan and Israel in Antiquity, 230, 237.

51 M. Liverani, Nie tylko Biblia, 112. E. Lipiński zwraca uwagę, że ,,brak wszelkich informacji pozabiblijnych o panowaniu Dawida i Salomona, poza wzmiankami o „domu Dawida” w IX wieku p.n.e. niezbicie dowodzi, że chodzi tu o nieznaczne podówczas państewko w górzystej części Kanaanu”. Według tego uczonego Juda i Izrael były od początku dwiema odrębnymi jednostkami politycznymi i pozostały nimi przez cały czas panowania Dawida i Salomona. Zjednoczone Królestwo składało się z tych dwóch jednostek, które były połączone unią personalną, zob. E. Lipiński, Studia z dziejów i kultury, 286-287.

52 Na taki argument badaczy zwraca uwagę T. Römer, L'invention de Dieu, 130.

53 M. Liverani, Nie tylko Biblia, 112-113. 
odzwierciedla w rzeczywistości okres prosperity Królestwa Izraela w czasach Omrydów (i ich następców) ${ }^{54}$. Przypadek Megiddo może stanowić ciekawe nawiązanie do tej koncepcji, bowiem odkryte tu monumentalne budowle początkowo łączone $\mathrm{z}$ panowaniem Salomona - stajnie i sześciokomorowa brama - w rzeczywistości powstały najprawdopodobniej w czasach rozkwitu Północnego Królestwa i związane są z działalnością budowlaną jego władców.

Wbrew zwolennikom chronologii „wysokiej”, którzy sugerują, że król Salomon zbudował potężną bramę w Megiddo warstwy VA-IVB, zniszczoną przez Szeszonka, uczeni przyjmujący „niską” chronologię uważają, że faraon ten nie zniszczył miasta, ale podbił je, co kazał upamiętnić wzniesioną tu stelą, a obiekty z okresu późnego żelaza IIA wzniósł Omri, podobnie jak zbudował swoją nową stolicę - Samarię. Aktywność budowlana tego króla wzmiankowana jest w Biblii: „Potem nabył za dwa talenty srebra od Szemera górę Szomron i obwarował tę górę, i nazwał gród, który zbudował, Samaria według imienia właściciela tej góry Szemera” (1 Krl 16,24). Chronologia „,niska", chociaż nie jest zależna od tekstu Biblii, to w oczywisty sposób przyjmuje wiarygodność wielu biblijnych przekazów ${ }^{55}$, jak choćby tego dotyczącego działalności Omriego. Żeby móc się przekonać, czy rzeczywiście władcy panujący w Izraelu byli na tyle potężni, by mogli zrealizować wielkie przedsięwzięcia budowlane w Megiddo w epoce żelaza (IIA i IIB), przyjrzyjmy się teraz Królestwu Północnemu w okresie jego świetności.

\section{Królestwo Północne w czasach prosperity}

Świadectwa archeologiczne oraz źródła pozabiblijne dowodzą, że tak długo, jak współistniały obydwa hebrajskie królestwa, Izrael był znacznie bardziej rozwinięty niż Juda, i to pod wieloma względami: w sferze rozwoju terytorialnego, siły militarnej, liczby mieszkańców czy osiągnięć w zakresie kultury materialnej. Jak się wydaje, także w niezwykle istotnej cywilizacyjnie dziedzinie zastosowania pisma archeologia dostarcza dowodów na to, że było ono używane w Izraelu

54 E.A. Knauf, P. Guillaume, A History of Biblical Israel, 76.

55 K.L. Noll, Canaan and Israel in Antiquity, 251. 
już w pierwszej połowie VIII stulecia przed Chr., co najmniej pół wieku wcześniej niż w Judzie ${ }^{56}$. Terytorium północne rozwijało się dynamiczniej od południowej krainy już w epoce brązu ${ }^{57}$. Zdaniem Israela Finkelsteina pierwszy północnoizraelski byt państwowy, jeszcze nieformalny, istniał w $\mathrm{X}$ wieku przed Chr. na obszarze przedstawionym w Biblii jako rdzeń królestwa Saula (m.in. 1 Sm 10,5), a jego kres nastąpił wraz z najazdem faraona Szeszonka ${ }^{58}$. Po upadku tej pierwszej północnoizraelskiej jednostki terytorialnej pojawił się nowy organizm polityczny z ośrodkiem w mieście Tirsa, który należy wiązać z początkami północnego Królestwa ${ }^{59}$. W tym czasie Juda

56 I. Finkelstein, „A Corpus of North Israelite Texts”, 263; tenże, „History of Ancient Israel”, 380; I. Finkelstein, B. Sass, ,The West Semitic Alphabetic Inscriptions", 149-220. Według autorów hebrajskie inskrypcje pojawiają się pierwszy raz pod koniec okresu żelaza IIA (IX wiek przed Chr.) w Gat na południu i Rehov na północy. Dla tego okresu, poza pojedynczą protokananejską inskrypcją pochodzącą z Jerozolimy, nie ma świadectw piśmiennictwa w centralnej części Izraela i Judy. Znamienne jest to, że brak w ogóle hebrajskich inskrypcji w głównych miastach Omrydów: Megiddo, Samarii, Jizreel, Yokneam i Hazor. Napisy, które pojawiają się w IX wieku (i wcześniej), w tym również monumentalne kamienne inskrypcje, nie wskazują na umiejętność komponowania skomplikowanych tekstów. Jak piszą autorzy, umiejętności skrybów sporządzających spisy towarów nie mogą być utożsamiane ze zdolnością tworzenia tekstów biblijnych. Pierwsze inskrypcje zawierające dłuższy i bardziej skomplikowany tekst, mogący już przypominać kompozycje biblijne, pojawiają się w pierwszej połowie VIII wieku w Królestwie Izraela (Tell Deir Alla Balaam) i w Kuntillet 'Ajrud. Powyższe obserwacje wydają się zatem wykluczać możliwość kompozycji tekstów biblijnych przed pierwszą połową VIII wieku przed Chr. Zob. na ten temat S. Ahituv, Echoes from the Past, 433-465; N. Na'aman, „A New Outlook”, 39-51. Pewne światło na problem pojawienia się piśmiennictwa na obszarze starożytnej Palestyny może rzucić analiza inskrypcji na ostrakonie znalezionym w Khirbet Qeiyafa (pismo jest prawdopodobnie protokananejskie, ostrakon datuje się na koniec XI-początek X w. przed Chr.), która budzi jednak wiele kontrowersji; na ten temat zob. M. Münnich, $C z y$ istniało królestwo Dawida?, 85-99.

57 I. Finkelstein, The Forgotten Kingdom, 13-22.

58 I. Finkelstein, The Forgotten Kingdom, 37-61, tenże, Dawid i Salomon, 61-70. Autor nazywa ten organizm polityczny Gibeon/Gibeah polity. Warto dodać, że na jego obszarze wykopaliska odsłoniły najstarsze fortyfikacje zawierające mur kazamatowy, a właśnie ten typ fortyfikacji będzie charakterystyczny dla miast i twierdz Północnego Królestwa.

59 I. Finkelstein, The Forgotten Kingdom, 63-82. 
była najprawdopodobniej, na co wskazują rezultaty badań archeologicznych, skromnym obszarem, zamieszkiwanym głównie przez ludność wiejską ${ }^{60}$.

Pierwszy okres dobrobytu gospodarczego i rozwoju terytorialnego Królestwa Północnego wiąże się z panowaniem dynastii Omrydów, władającej Izraelem w latach 884-842 przed Chr. ${ }^{61}$ ze swej nowo wybudowanej stolicy - Samarii. Najważniejszą uchwytną archeologicznie aktywnością tego okresu były monumentalne prace budowlane, obejmujące wznoszenie nowych miast (wspomniana Samaria oraz Jizreel) i twierdz (położone w Moabie Jahaz i Atarot ${ }^{62}$ ) ufortyfikowanych murem kazamatowym, a także przebudowa już istniejących ośrodków i wyposażanie ich w podobnego typu fortyfikacje (Hazor, Gezer), które były charakterystyczną cechą architektury Omrydów ${ }^{63}$. W Megiddo Omrydzi zbudowali dwa lub trzy wyszukane pałace ${ }^{64}$. Za panowania tej dynastii Izrael znacznie powiększył swoje terytorium, włączając w nie Moab, Gilead, rejon Hazor, Galileę i na zachodzie wybrzeże Morza Śródziemnego.

Zdaniem I. Finkelsteina Omrydzi zdominowali mniejszą, słabszą Judę. Mogą na to wskazywać informacje zawarte w przekazie biblijnym, według którego judzki król Jozafat wspomagał władcę Izraela w działaniach wojennych (2 Krn 18,28-29), córka króla izraelskiego Achaba, Atalia, została wydana za mąż za Jorama, króla Judy (2 Krl 8,18), zaś ich syn Achazjasz udał się wraz z królem Izraela Joramem (jako jego wasal?) na wojnę przeciw Aramejczykom $(2 \mathrm{Krl} \mathrm{8,28)})^{65}$. Może więc nie w państwie Dawida i Salomona, ale

${ }^{60}$ I. Finkelstein, N.A. Silberman, The Bible Unearthed, 162; M. Broshi. I. Finkelstein, „The Population of Palestine in Iron Age II”, 47-60. Szerzej na ten temat I. Finkelstein, The Archaeology of the Israelite Settlement.

${ }_{61}$ I. Finkelstein, The Forgotten Kingdom, 83.

62 I. Finkelstein, O. Lipschits, ,Omride Architecture in Moab”, 29-42.

63 I. Finkelstein, The Forgotten Kingdom, 85-105. Poza murem kazamatowym autor wymienia pozostałe cechy monumentalnej architektury w czasach Omrydów: podium (podwyższona platforma), sześciokomorowe bramy miejskie, fosa wykuta w skale, pochyła konstrukcja wspierająca mury kazamatowe.

64 D. Ussishkin, Megiddo - Armageddon, 333-370.

65 K.L. Noll, Canaan and Israel in Antiquity, 281-283; I. Finkelstein, „A Corpus of North Israelite Texts", 265. 
$\mathrm{w}$ istniejącym $\mathrm{w}$ następnym stuleciu tworze politycznym, złożonym z Królestwa Północnego i zdominowanego przezeń Królestwa Judy, należałoby dopatrywać się Zjednoczonej Monarchii obejmującej terytorium od Dan do Beer-Szeby ${ }^{66}$.

Potęgę Królestwa Izraela za panowania Omrydów poświadczają ważne źródła pozabiblijne, czego nie da się powiedzieć o Judzie i władających nią Dawidzie (tu wyjątkiem, jednak i tak dość skromnym, jest tzw. stela z Tel Dan ${ }^{67}$ ) i Salomonie. W inskrypcji asyryjskiego władcy Salmanasara III znajduje się wzmianka o królu Izraela Achabie, który jest wymieniony wśród jego najsilniejszych przeciwników w bitwie pod Karkar w Syrii (853 r. przed Chr.). Pochodząca z IX wieku przed Chr. stela króla Moabu Meszy ${ }^{68}$ zawiera informację o ekspansji Omriego i jego syna Achaba na ziemie tego królestwa, a w słynnej inskrypcji z Tel Dan, którą kazał wykonać król Damaszku Hazael, wspomina się o pokonaniu przez niego (i zabiciu) władcy Izraela i króla z „domu Dawida"69.

Po krótkim okresie upadku w drugiej połowie IX wieku przed Chr., spowodowanym przez Hazaela, Północne Królestwo osiągnęło drugi i ostatni okres prosperity, którego apogeum przypada na czasy Jeroboama II (788-747 przed Chr.) ${ }^{70}$. Według przekazu biblijnego ojciec Jeroboama, Joasz, pokonał i wziął do niewoli króla judzkiego, co może wskazywać na podporządkowanie również w tym okresie Judy Izraelowi (2 Krl 14,8-14). Zakrojona na szeroką skalę działalność budowlana Jeroboama II widoczna jest w poświadczonych archeologicznie renowacjach najważniejszych miast (jak Hazor czy Gezer). Sprawne rządy tego monarchy widzimy w analizowanym wyżej

66 I. Finkelstein, Dawid i Salomon, 88.

${ }^{67}$ Literatura na temat inskrypcji, którą zawiera stela z Tel Dan jest obszerna, zob. np. N. Na'aman, „Three notes on the Aramaic”, 92-104. Inskrypcja ta jest pierwszym tekstem pozabiblijnym, w którym około 100 lat po panowaniu Dawida pojawia się jego imię (w przeciwieństwie do Salomona, o którym wzmianek pozabiblijnych brak).

${ }^{68} \mathrm{Na}$ ten temat zob. np. T. Römer, L'invention de Dieu, 149-153. Inskrypcja na steli Meszy potwierdza też rozmaitość miejsc kultu w Izraelu za panowania Omrydów.

69 I. Finkelstein, „The Two Kingdoms”, 149.

70 I. Finkelstein, The Forgotten Kingdom, 129. 
projekcie związanym ze stajniami w Megiddo, a także chociażby w fundacji ufortyfikowanego portu morskiego w Dor. Zrealizowanie wszystkich tych przedsięwzięć nie byłyby możliwe bez sprawnej infrastruktury i administracji, której istnienie mogą potwierdzać niektóre interpretacje ostrakonów z Samarii ${ }^{71}$.

Za panowania Jeroboama II Królestwo Izraela osiągnęło szczyt rozwoju zarówno pod względem terytorialnym, jak i demograficznym, ekonomicznym oraz kulturowym. Zapewne z ogólnym dobrobytem $\mathrm{w}$ tym okresie, a także z wczesnymi wpływami asyryjskimi, należy wiązać pojawienie się w Królestwie Północnym, w pierwszej połowie VIII wieku przed Chr., inskrypcji o treści bardziej skomplikowanej od na przykład prostych spisów towarów ${ }^{72}$. Jest zatem całkiem prawdopodobne, że to w czasach Jeroboama II mógł w jego państwie powstać korpus tekstów, który według I. Finkelsteina obejmował kwestie tożsamości i terytorium Izraela i zawierał wczesną wersję panizraelskiej ideologii Zjednoczonej Monarchii ${ }^{73}$.

W 732 roku przed Chr. asyryjski król Tiglatpilesar III dokonał aneksji Północnego Królestwa i położył kres jego istnieniu. Po upadku Izraela powstały za Jeroboama II korpus tekstów mógł wraz z uciekinierami, którzy przybyli z północy na teren Królestwa Judy, zostać przyniesiony na południe, gdzie następnie stał się podstawą biblijnej „historiografii” i posłużył budowaniu ideologicznego konstruktu wielkiej Zjednoczonej Monarchii ${ }^{74}$.

\section{Konkluzja}

Analizowane tutaj wielkie przedsięwzięcia budowlane w Megiddo warstw VA-IVB oraz IVA - stajnie i brama 2156 - mogły być realizowane jedynie przez silne państwo, dobrze zarządzane przez

71 A. Kleiman, ,A North Israelite”, 355.

72 I. Finkelstein, „History of Ancient Israel”, 381.

73 I. Finkelstein, „A Corpus of North Israelite Texts”, 262.

74 I. Finkelstein, The Forgotten Kingdom, 155-158. Uczony ten jest zdania, że Izrael i Juda pojawiły się niezależnie i rozwijały obok siebie; w X wieku nie rządził nimi jeden monarcha. Według niego idea Zjednoczonej Monarchii pojawiła się w Izraelu za czasów Jeroboama II, który narzucił swą dominację Królestwu Judy, a następnie, po upadku Królestwa Północnego, została przejęta przez Judę. 
potężnego władcę. Przez kilkadziesiąt lat po ich odkryciu uczeni w znacznej większości uważali, że władcą tym był król Salomon. Hipoteza ta, jak się wydawało, miała oparcie w przekazie biblijnym i oznaczała przyjęcie za właściwą tzw. chronologii ,wysokiej”. Rezultaty podjętych ponownie badań pozostałości interesujących nas obiektów oraz przeprowadzonych w ostatnich latach nowych prac wykopaliskowych wydają się wskazywać, że bardziej wiarygodna i obiektywna jest chronologia ,niska”. W jej ustalaniu szczególne znaczenie ma zastosowanie metody datowania radiowęglowego oraz uzgodnionej ostatnio względnej chronologii Lewantu w epoce żelaza, obejmującej sekwencję faz typologii ceramiki opartą na stratygrafii. Zastosowanie „niskiej” chronologii pozwala przyjąć, że odpowiednio silnym państwem, które było w stanie realizować wielkie przedsięwzięcia budowlane w Megiddo warstw VA-IVB oraz IVA było Królestwo Północne w dwóch okresach swojej prosperity: za panowania królów z dynastii Omriego oraz za rządów Jeroboama II. „Niska” chronologia nie neguje całkowicie przekazu biblijnego, ale nie jest od niego zależna w takim stopniu, jak ma to miejsce w przypadku chronologii „wysokiej”. Uwolnienie się od tej zależności, a zarazem uznanie wiarygodności wielu fragmentów Biblii, pozwala na odtworzenie względnie obiektywnego obrazu przeszłości. Uzyskanie pełnej akceptacji różnych środowisk odnośnie chronologii Lewantu, podobnie jak w kwestii historycznej wiarygodności przekazu biblijnego, jest oczywiście niemożliwe i prawdopodobnie nigdy nie zostanie osiągnięte.

\section{The problem of Solomon's building activity in the light of the latest archaeological discoveries in Megiddo}

Abstract: The article presents the latest arrangements regarding the identification
of monumental pillar structures and the gate 2156 at Megiddo, based primarily on
the analysis of archaeological data collected during excavations in the 2018 season
(gate 2156) and surveys resumed in 1998 and continued in subsequent seasons (city of
Stratum IV). These results indicate that monumental buildings discovered in the 1920 ,
initially connected with the rule of Solomon - stables and a six-chamber gate - in fact,
most likely arose during the prosperity of the Northern Kingdom under the rule of the
Omrid's dynasty and Jeroboam II.

Keywords: Megiddo; Bible; archeology; Northern Kingdom; Omrids dynasty; Jeroboam II, Solomon 


\section{Bibliografia}

Aharoni, Y., „The Stratification of Israelite Megiddo”, Journal of Near Eastern Studies 31 (1972) nr 4, 302-311.

Ahituv, S., Echoes from the Past: Hebrew and Cognate Inscriptions from the Biblical Period, Jerusalem 2008.

Albright, W.F., Archeologia Palestyny, S. Majchrzak (przeł.), Warszawa 1964. Broshi, M., Finkelstein, I., „The Population of Palestine in Iron Age II”, Bulletin of the American Schools of Oriental Research 287 (1992), 47-60.

Boaretto, E., Jull, A.J.T., Gilboa, A., Sharon, I., „Dating the Iron age I/II Transition in Israel: First Intercomparison Results", Radiocarbon 47 (2005) nr 1, $39-55$.

Cantrell, D.O., Finkelstein, I., „A Kingdom for a Horse: The Megiddo Stables and Eighth Century Israel", w: I. Finkelstein, D. Ussishkin, B. Halpern (red.), Megiddo IV. The 1998-2002 Seasons, Tel Aviv 2006, 643-665.

Cline, E.H., The Battles of Armageddon: Megiddo and the Jezreel Valley from the Bronze Age to the Nuclear Age, Ann Arbor (MI) 2002.

Davies, G.I., Megiddo, Cambridge 1986.

Davies, P.L., In Search of Ancient Israel, wyd. 2, Sheffield 2015 (wyd. 1, 1992).

Finkelstein, I., The Archaeology of the Israelite Settlement, Leiden 1988.

Finkelstein, I., The Forgotten Kingdom. The Archaeology and History of Northern Israel, Atlanta (GA) 2013.

Finkelstein, I., „A Low Chronology Update: Archaeology, History and Bible”, w: T.E. Levy, T. Higham (red.), The Bible and Radiocarbon Dating. Archaeology, Text and Science, London 2014, 31-42.

Finkelstein, I., „History of Ancient Israel: Archaeology and the Biblical Record - the View from 2015", Rivista Biblica 63 (2015), 371-392.

Finkelstein, I., „The Two Kingdoms: Israel and Judah”, w: I. Finkelstein, A. Mazar, B.B. Schmidt (red.), The Quest for The Historical Israel. Debating Archaeology and the History of Early Israel. Invited Lectures Delivered at the Sixth Biennial Colloquium of the International Institute for Secular Humanistic Judaism, Detroit, October 2005, Atlanta (GA) 2015, 147-157.

Finkelstein, I., „A Corpus of North Israelite Texts in the Days of Jeroboam II?”, Hebrew Bible and Ancient Israel 3 (2017), 262-289.

Finkelstein, I., Adams, M.J., Hall, E., Levy, E., „The Iron Age Gates of Megiddo: New Evidence and Updated Interpretations", Tel Aviv. Journal of the Institute of Archaeology of Tel Aviv University, 46 (2019) $\mathrm{nr}$ 2, 167-191.

Finkelstein, I., Lipschits, O., „Omride Architecture in Moab: Jahaz and Ataroth”, Zeitschrift des Deutschen Palästina-Vereins 126 (2010), 29-42.

Finkelstein, I., Piasetzky, E., „The Iron Age Chronology Debate: Is the Gap Narrowing?", Near Eastern Archaeology 74 (2011) nr 1, 50-54. 
Finkelstein, I., Sass, B., „The West Semitic Alphabetic Inscriptions. Late Bronze II to Iron IIA: Archaeological Context, Distribution and Chronology", $\mathrm{He}$ brew Bible and Ancient Israel 2 (2013) z. 2, 149-220.

Finkelstein, I., Silberman, N.A., The Bible Unearthed. Archaeology's New Vision of Ancient Israel and the Origin of its Sacred Texts, New York-London-Toronto-Sydney 2002.

Finkelstein, I., Silberman, N.A., Dawid i Salomon, A. Weseli (tłum.), Warszawa 2007.

Finkelstein, I., Ussishkin, D., „Back to Megiddo”, Biblical Archaeology Review 20 (1994) nr 1, 26-33, 36-37, 39-43.

Finkelstein, I., Ussishkin, D., Halpern, B. (red.), Megiddo III. The 1992-1996 Seasons (Monographs of the Institute of Archaeology of Tel Aviv University 18), t. 1-2, Tel Aviv 2000.

Finkelstein, I., Ussishkin, D., Halpern, B. (red.), Megiddo IV. The 1998-2000 Seasons (Monographs of the Institute of Archaeology of Tel Aviv University 24), t. 1-2, Tel Aviv 2006.

Finkelstein, I., Ussishkin, D., Cline, E.H. (red.), Megiddo V. The 2004-2008 Seasons (Monographs of the Institute of Archaeology of Tel Aviv University 31), t. 1-3, Winona Lake (IN) 2013

Fisher, C.S., The Excavation of Armageddon, Chicago (IL) 1929.

Franklin, N., „Megiddo's Stables: Trading Egyptian Horses to the Assyrian Empire", thetorah.com/megiddos-stables-trading-egyptian-horses-to-the-assyrian-empire/, 2014.

Franklin, N., „Correlation and Chronology: Samaria and Megiddo Redux”, w: T.E. Levy, T. Higham (red.), The Bible and Radiocarbon Dating. Archaeology, Text and Science, London 2014, 310-322.

Franklin, N., „Entering the Arena: The Megiddo Stables Reconsidered”, w: O. Lipschits, Y. Gadot, M.J. Adams (red.), Rethinking Israel. Studies in the History and Archaeology of Ancient Israel in Honor of Israel Finkelstein, Winona Lake (IN) 2017, 87-101.

Garfinkel, Y., „The Birth and Death of Biblical Minimalism”, Biblical Archaeology Review 37 (2011) nr 3, 46-53.

Green, J., „Model of 'King Solomon's Stables' at Megiddo (Cat. 34)”, w: J. Green, E. Teeter, J.A. Larson (red.), Picturing the Past: Imaging and Imagining the Ancient Middle East (Oriental Institute Museum Publications 34), Chicago (IL) 2012, 161-164.

Guy, P.L.O., New Light from Armageddon: Second Provisional Report (1927-29) on the Excavations at Megiddo in Palestine, Chicago (IL) 1931.

Guy, P.L.O., Megiddo Tombs, Chicago (IL) 1938.

Herzog, Z., Das Stadttor in Israel und in den Nachbarländern, Mainz 1986. 
Herzog, Z., Singer-Avitz, L., „Sub-Dividing the Iron Age IIA in Northern Israel: A Suggested Solution to the Chronological Debate", Tel Aviv 33 (2006) nr 2, 163-195.

Kempinski, A., Megiddo: A City-State and Royal Centre in North Israel, Münich 1989.

Kleiman, A., „A North Israelite Royal Administrative System and its Impact on Late-Monarchic Judah", Hebrew Bible and Ancient Israel 6 (2017) nr 3, 354-371.

Kleiman, A., Finkelstein, I., „The Date of Building 338 at Megiddo: Eppur Si Muove!", Israel Exploration Journal 68 (2018) nr 1, 50-55.

Knauf, E.A., „1-2 Rois”, w: T. Römer, J.-D. Macchi, C. Nihan (red.), Introduction à l'Ancien Testament, Genewa 2009, 384-393.

Knauf, E.A., Data and Debates: Essays in the History and Culture of Israel and its Neighbors in Antiquity, Münster 2013.

Knauf, E.A., Guillaume, P., A History of Biblical Israel. The Fate of the Tribes and Kingdoms from Merenptah to Bar Kochba, Scheffield 2016.

Lamon, R.S., The Megiddo Water System, Chicago (IL) 1935.

Lamon, R.S., Shipton, G.M., Megiddo I. Seasons of 1925-34: Strata I-V, Chicago (IL) 1939.

Lemche, N.P., „The Same Old Story”, w: Ł. Niesiołowski-Spanò, C. Peri, J. West (red.), Finding Myth and History in the Bible. Scholarschip, Scholars and Errors. Essays in Honor of Giovanni Garbini, Sheffield-Bristol 2016, 84-95.

Levy, T.E., Higham, T. (red.), The Bible and Radiocarbon Dating. Archaeology, Text and Science, London 2014.

Lipiński, E., Studia z dziejów i kultury starożytnego Bliskiego Wschodu, Kraków 2013.

Liverani, M., Nie tylko Biblia. Historia starożytnego Izraela, J. Puchalski (tłum.), Warszawa 2010.

Loud, G., The Megiddo Ivories, Chicago (IL) 1939.

Loud, G., Megiddo II. Seasons of 1935-39: Text and Plates, Chicago (IL) 1948.

Majewski, M., Pięcioksiag odczytany na nowo. Przestanie autora kapłańskiego (P) i jego wpływ na napisanie Pięcioksięgu, Kraków 2018.

May, H.G., Material Remains of the Megiddo Cult, Chicago (IL) 1935.

Mazar, A., Archaeology of the Land of the Bible 10.000-586 B.C.E., New York 1990.

Mazar, A., „The Debate over the Chronology of the Iron Age in the Southern Levant: Its History, the Current Situation, and a Suggested Resolution", w: T.E. Levy, T. Higham (red.), The Bible and Radiocarbon Dating. Archaeology, Text and Science, London 2005, 15-30.

Mazar, A., „The Spade and the Text: The Interaction between Archaeology and Israelite History Relating to the Tenth-Ninth Centuries BCE", 
w: H.G.M. Williamson (red.), Unerstanding the History of Ancient Israel, Oxford 2007, 143-147.

Mazar, A., „The Iron Age Chronology Debate: Is the Gap Narrowing? Another Viewpoint", Near Eastern Archaeology 74 (2011) nr 2, 105-111.

Mazar, A., „The Search for David and Solomon: an Archaeological Perspective”, w: I. Finkelstein, A. Mazar, B.B. Schmidt (red.), The Quest for The Historical Israel. Debating Archaeology and the History of Early Israel. Invited Lectures Delivered at the Sixth Biennial Colloquium of the International Institute for Secular Humanistic Judaism, Detroit, October 2005, Atlanta (GA) 2015, 117-139.

Münnich, M., Czy istniało królestwo Dawida? Najnowsze wykopaliska w Khirbet Qeiyafa, Lublin 2014.

Na'aman, N., „Three notes on the Aramaic inscription from Tel Dan”, Israel Exploration Journal 50 (2000) nr 1-2, 92-104.

Na'aman, N., ,A New Outlook at Kuntillet 'Ajrud and its Inscriptions”, Maarav 20 (2013) nr 1, 39-51.

Niesiołowski-Spanò, Ł., Mityczne poczatki miejsc świętych w Starym Testamencie, Warszawa 2003.

Noll, K.L., Canaan and Israel in Antiquity: A Textbook on History and Religion, wyd. 2, London-New Delhi-New York-Sydney 2013.

Nussbaum, J., Stratigraphic Discussion of the "Solomonic" City Gate at Megiddo, Basel 2018.

Römer, T., L'invention de Dieu, Paris 2014.

Ronowska, E., „Biblijne Megiddo w świetle rezultatów badań archeologicznych", Collectanea Theologica 89 (2019) nr 3, 5-41.

Schumacher, G., Tell el-Mutesellim 1, Leipzig 1908.

Shiloh, Y., ,Solomon's Gate at Megiddo as Recorded by its Excavator, R. Lamon", Levant 12 (1980), 69-76.

Shipton, G.M., Notes on the Megiddo Pottery of Strata VI-XX, Chicago (IL) 1939.

Stern, E., „Hazor, Dor and Megiddo in the Time of Ahab and under Assyrian Rule", Israel Exploration Journal 40 (1990) nr 1, 12-30.

Thompson, T.L., The Mythic Past: Biblical Archaeology and the Myth of Israel, New York 1999.

Toffolo, M.B., Arie, E., Martin, M.A.S., Boaretto, E., Finkelstein, I., „Absolute Chronology of Megiddo, Israel, in the Late Bronze and Iron Ages: High-Resolution Radiocarbon Dating”, Radiocarbon 56 (2014) nr 1, 221-244.

Ussishkin, D., „Was the 'Solomonic' City Gate at Megiddo Built by King Solomon?", Bulletin of the American Schools of Oriental Research 239 (1980), 1-18. 
Ussishkin, D., „Notes on Megiddo, Gezer, Ashdod and Tel Batach in the Tenth to Ninth Centuries B.C.", Bulletin of the American Schools of Oriental Research 277/278 (1990), 71-91.

Ussishkin, D., „Area G. Soundings in the Late Bronze Age Gate”, w: I. Finkelstein, D. Ussishkin, B. Halpern (red.), Megiddo III, Tel Aviv 2000, 104-122.

Ussishkin, D., Megiddo - Armageddon. The Story of the Canaanite and Israelite City, Jerusalem 2018.

Watzinger, C., Tell el-Mutesellim 2, Leipzig 1929.

Yadin, Y., „Solomon's City Wall and Gate at Gezer”, Israel Exploration Journal 8 (1958) $\mathrm{nr}$ 2, 80-86.

Yadin, Y., „New Light on Solomon's Megiddo”, Biblical Archaeologist 23 (1960) nr 2, 62-68.

Yadin, Y., „Megiddo of the Kings of Israel”, Biblical Archaeologist 33 (1970) nr 3, 66-96.

Yadin, Y., Hazor with a Chapter on Israelite Megiddo, London 1972.

Yadin, Y., „The Megiddo Stables”, w: F.M. Cross, W.E. Lemke, P.D. Miller (red.), Magnalia Dei, the Mighty Acts of God: Essays on the Bible and Archaeology in Memory of G. Ernst Wright, Garden City (KS) 1976, 249-252.

Zarzecki-Peleg, A., Yadin's Expedition to Megiddo: Final Report of the Archaeological Excavations (1960, 1966, 1967 and 1971/2 Seasons) (QEDEM 56), Jerusalem 2016. 